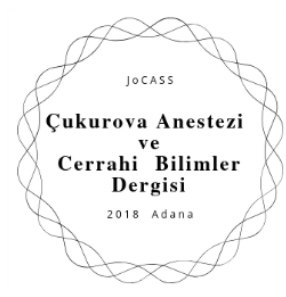

\title{
INVESTIGATION OF KNOWLEGE ABOUT PROSTATE CANCER SCREENING AND REGULAR EXERCISE AWARENESS IN MEN OVER 40 YEARS AGE ADMITTED TO HOSPITAL

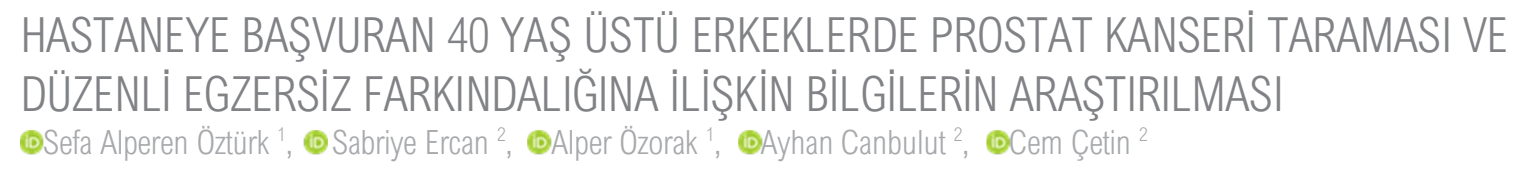

1 Suleyman Demirel University, Medicine Faculty, Department of Urology, Isparta, Turkey.

2 Suleyman Demirel University, Medicine Faculty, Sports Medicine Department, Isparta, Turkey.

Sorumlu Yazar/Corresponding Author: Sabriye Ercan E-mail: sabriyeercan@gmail.com

Geliş Tarihi/Received: 25.08.2020 Kabul Tarihi-Accepted: 31.08.2020 Available Online Date/Çevrimiçi Yayın Tarihi: 31.08.2020

Cite this article as: Öztürk SA, Ercan S, Özorak A, Canbulut A, Çetin C. Examination of Prostate Cancer Screening Knowledge and Regular Exercise Awareness in Men Over 40 Years Old. J Cukurova Anesth Surg. 2020:3(2),105-115.

Doi: 10.36516/jocass.2020.45

\section{$\ddot{\mathbf{O z}}$}

Amaç: Bu çalışmanın amacı; 40 yaşının üstündeki erkeklerde kanserden koruyucu bir etken olan düzenli egzersize ait bilinç düzeyinin ve prostat kanseri taramaları bilgisinin incelenmesidir.

Materyal ve Metot: Çalışma, prospektif olarak yürütüldü. Hastanemize başvuran 40 yaşının üstündeki erkeklerin demografik veri formunu, 'Prostat Kanseri Taramaları Bilgi Testi (PKTBT)'ni ve 'Egzersiz/Fiziksel Aktivite Bilinç Düzeyi Anketi’ni cevaplaması istendi.

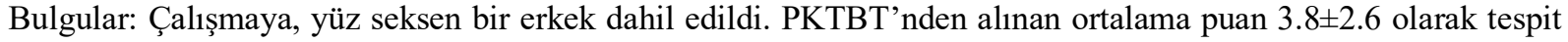
edildi. Aile öyküsü pozitif olan kişilerin tarama bilgi testinden aldığı puanlar daha yüksekti $(\mathrm{p}=0.002)$. Eğitimin artması tarama testi bilgisini arttırıyordu $(\mathrm{p}<0.05)$. Tarama testi bilgisi düşük olanlar, tarama programlarına daha az katılıyordu $(\mathrm{p}<0.05)$. Sağlık-Egzersiz/Fiziksel Aktivite Bilinç Düzeyi Anketi'nden alınan ortalama puanın $106.3 \pm 27.2$ olduğu bulundu. Kırsalda yaşayanların fiziksel aktivite bilinç düzeyi daha düşük iken eğitim arttıkça fiziksel aktivite alışkanlı̆g artıyordu ( $<0.05)$. Tarama testi bilgisi yüksek olanların hem fiziksel aktivite bilinci hem de alışkanlığı daha yüksekti $(\mathrm{p}<0.05)$.

Sonuç: Sonuç olarak 40 yaş üstü erkeklerin prostat kanseri tarama testleri hakkında düşük düzeyde, egzersiz / fiziksel aktivite farkındalığı konusunda orta düzeyde bilgiye sahip oldukları belirlenmiştir. Toplumda, prostat kanserin erken tanısını kolaylaştıran tarama testleri bilgisi arttırılırken bir yandan da sağlıklı yaşam alışkanlıkları konusunda bilgi ve alı̧skanlık düzeyinin arttırılması gerekmektedir. 


\begin{abstract}
Aim: In this study, we aimed to examine level of awareness of regular exercise, which is a protective factor from cancer, and knowledge about prostate cancer screening (PCaS) in men over 40 years of age.

Material and method: The study was conducted prospectively. Men over 40 years of age who applied to our hospital were asked to answer the demographic information form, "PCaS Test", and "Exercise/Physical Activity Awareness Level Questionnaire (E/PAALQ)".

Results: One hundred eighty-one men were included in this study. The mean score obtained from PCaS Test was 3.8 \pm 2.6 . Individuals, who had a positive family history, obtained higher scores from PCaS ( $\mathrm{p}=0.002)$. The increase in the level of education was increasing the level of knowledge about PCaS ( $<<0.05)$. Individuals, who had low level of knowledge about screening test, were participating less in screening programs $(\mathrm{p}<0.05)$. The mean score obtained from E/PAALQ was $106.3 \pm 27.2$. While the level of the physical activity awareness of the rural residents was lower, physical activity habit increased as the level of education increased $(\mathrm{p}<0.05)$. In individuals with high level of knowledge about screening test, both awareness and habit of physical activity were higher $(\mathrm{p}<0.05)$.

Conclusion: As a result, it was determined that men over the age of 40 have low-level of knowledge about prostate cancer screening tests and have moderate-level knowledge about exercise/physical activity awareness. In society, while increasing knowledge of screening tests that facilitate early diagnosis of prostate cancer, knowledge and habit level should be increased on subject of healthy living habits also.
\end{abstract}

Keywords: Exercise, physical activity, prostate cancer, screening.

\section{Introduction}

Cancer is the second most common cause of death after cardiovascular diseases ${ }^{1}$. Prostate cancer is the most frequently diagnosed cancer, and it ranks second among all malignant neoplasms ${ }^{2,3}$. According to the data in our country, the incidence of prostate cancer is 35-37.6 / $100000^{3,4}$. This number demonstrates that $28 \%$ of the male cancer cases in our country are diagnosed with prostate cancer, and prostate cancer is the second most common type of cancer in $\mathrm{men}^{3,4}$. When the figures of the current cancer incidence are projected to 2050 , it is predicted that the incidence of cancer will increase by 3 times ${ }^{5}$. Fortunately, prostate cancer has a slowly progressive nature ${ }^{6}$. It is possible to diagnose in the early stage with screening tests, and the eradication success of prostate cancer detected at an early stage is high $^{4,7}$.
Upon examining the literature, it is observed that the main factors causing the development of prostate cancer and/or preventing early diagnosis are listed as advanced age, positive family history, black race, unhealthy eating habits, lack of exercise, smoking, excessive alcohol consumption, obesity, low socioeconomic status, lack of knowledge about the disease, low level of education, lack of health insurance, difficulty in access to healthcare institutions, geographical region, genetic mutations and some occupational groups exposed to carcinogenic substances ${ }^{1,8-11}$. In noncommunicable diseases such as cancer, the main goal should be to intervene in the risk factors that can be modified and to provide primary protection ${ }^{12,13}$. Developing the levels of knowledge/awareness about protective health and physical activity habits are thought to be the main factors that can be intervened.

The protective effect of physical activity on prevention of cancer development and progression originates from its effect on 
the sex hormones, insulin, insulin-related growth factor (IGF), adipokine signal, and the mechanisms on inflammatory pathways ${ }^{7,14,15}$. In fact, while regular physical activity decreases the levels of sex hormone, insulin and IGF-1 in serum, it increases the levels of IGF-binding protein 1 and sex hormone binding globulin $^{7,8,15}$. Thus, proliferation in prostate cells decreases and apoptosis in prostate tumor cells increases ${ }^{7,15}$. Adipokine supports tumor development with the presence and effect of obesity $^{7,12,15}$. Regular exercise plays a preventive role in the development of cancer with its protective effect from obesity and the balancing effect on adipokine levels and chronic inflammatory processes $^{7,12,15}$. Epidemiological studies confirm that increased physical activity decreases prostate cancer risk by 10 $30 \%{ }^{10,12}$.

The benefits of the exercise are not only primary protection from prostate cancer. Aerobic exercise, applied to patients diagnosed with prostate cancer and receiving treatment, has also positive contributions such as reducing cancerrelated fatigue, increasing quality of life, preserving and developing muscle strength $^{7,16,17}$. Physical activity at high levels leads to a reduction in prostate cancer-specific mortality rate ${ }^{7}$. Especially, the disease recurrence risk of patients with breast, colon, and prostate cancer decreases depending on exercise ${ }^{14}$. All this information suggests that the level of exercise awareness should be increased in order to provide primary, secondary and tertiary protection from cancer ${ }^{12}$.

Another suggestion of specialist organizations seeking with cancer to provide protection from cancer is to increase the level of knowledge of society about cancer screening programs ${ }^{8}$. In our country, when men over 40 years of age with a family history and men over 50 years of age without a family history apply to the healthcare facility for prostate cancer screening, Prostate-Specific Antigen (PSA) measurement and digital rectal examination are performed ${ }^{3,8}$. However, it is known that participation rates in prostate cancer screening programs in our country are $\operatorname{low}^{18}$. Especially in cancers in which early diagnosis with a serological marker is possible, such as prostate cancer, it is evident that the participation in cancer screening programs affects the level of knowledge of society about this subject ${ }^{8,19,20}$.

The lack of knowledge/awareness is known to be a hindrance to maintaining a healthy lifestyle, gaining exercise habits and providing participation in cancer screening. We also observe that the protective effect of exercise against cancer is not known by society. The aim of this study is to examine the level of awareness of regular exercise, which is a factor that protects from cancer, and the knowledge about prostate cancer screenings, in men over 40 years of age.

\section{Materials and Methods}

It was determined that the research results should reach 181 participants in order to reflect the population at $80 \%$ confidence level (and precision rate 0.05 ). Men, who came our hospital in order to be examined and/or treated for any reason, whose ages ranged between $40-80$ years and who were literate, constituted the population of the prospectively designed study. Men under 40 years of age and men over 80 years of age, and individuals with whom communication problems were experienced during the implementation of questionnaires were excluded from the study.

The participants were asked to answer the demographic data form prepared by the researchers ${ }^{19,21-24}$, the "Prostate Cancer Screening Knowledge (PCaS) Test"19, and 
the "Exercise/Physical Activity Awareness Level Questionnaire (E/PAALQ)"25. The participants were given the necessary time to ask questions and to share on the subject.

The study was approved by the decision of the local ethics committee numbered 138 dated 16/04/2019.

\section{Statistical analysis}

The Pearson chi-square and likelihood chisquare methods were used for the independence test. Prior to analysis, the normal distribution test was performed using the Shapiro-Wilk method. In order to determine whether there was a difference between the score averages the one-way ANOVA method was applied within the framework of general linear models. Kruskal-Wallis test method was used to compare prostate cancer knowledge level scores with other variables. All analyses were performed using SAS 9.4 (SAS Inst., 2019) version. Statistical significance level was accepted as $\mathrm{p}<0.05$. Data were presented as $\%$ (n) and mean \pm standard deviation.

Table 1. Sociodemographic characteristics of the participants

\begin{tabular}{lll}
\hline Sociodemographic characteristics & $\mathbf{\%}$ & $\mathbf{n}$ \\
\hline Educational Status & 1.1 & 2 \\
$\quad$ Literate & 23.8 & 43 \\
Elementary School & 14.9 & 27 \\
Secondary School & 27.6 & 50 \\
High School & 9.4 & 17 \\
Associate Degree & 21 & 38 \\
Undergraduate (Faculty / College) & 1.7 & 3 \\
Graduate & 0.5 & 1 \\
Doctorate & 62.4 & 113 \\
Working Status & 2.8 & 5 \\
Works full-time & 2.2 & 4 \\
Works part-time & 3.3 & 6 \\
$\quad$ Does not work & 29.3 & 53 \\
Retired but works full-time or part-time & & \\
Retired & 37.1 & 66 \\
Professional Status & 33.7 & 60 \\
$\quad$ Public servant & 29.2 & 52 \\
Worker & & \\
Self-employed & 27.12 & 48 \\
Level of Income & 63.3 & 112 \\
Income is less than the expenses & 9.6 & 17 \\
$\quad$ Income is equal to the expenses & & \\
Income is more than the expense & &
\end{tabular}


Table 2. The participants' healthy life habits and disease histories

\begin{tabular}{lll}
\hline Healthy life habits and history of disease & $\mathbf{\%}$ & $\mathbf{n}$ \\
& & \\
\hline Smoking status & 30.5 & 55 \\
Never smokes & 33.9 & 61 \\
Still smokes & 35.6 & 64 \\
Has given up smoking & & \\
Experiencing any problems/diseases related to prostate & 84 & 152 \\
No & 16 & 29 \\
Yes (Benign prostatic hyperplasia, prostatitis, other) & & \\
Prostate cancer history in the family & 88.4 & 159 \\
No & 2.2 & 4 \\
Himself & 5 & 9 \\
First-degree relative & 2.2 & 4 \\
Second-degree relative & 2.2 & 4 \\
Third-degree relative & & \\
Digital rectal examination habit & 77.1 & 138 \\
Never & 4.4 & 8 \\
Once in a six month & 8.4 & 15 \\
Once in a year & 1.7 & 3 \\
Once in two years & 8.4 & 15 \\
At irregular intervals & & \\
PSA measurement habit & 74.3 & 133 \\
Never & 3.9 & 7 \\
Once in a six month & 11.7 & 21 \\
Once in a year & 0.6 & 1 \\
Once in two years & 9.5 & 17 \\
At irregular intervals & & \\
& & \\
\hline & & \\
\hline
\end{tabular}

PSA: Prostate-Specific Antigen

Results

One hundred eighty-one men were included in this study. The average age of the participants was $52 \pm 9.2$ years, the average height was $172 \pm 6.7 \mathrm{~cm}$, the average body weight was $81 \pm 13 \mathrm{~kg}$, and the average body mass index was $27 \pm 4.1$ $\mathrm{kg} / \mathrm{m}^{2}$. Of the individuals included in the study, 95.6\% $(\mathrm{n}=172)$ were married. Of the participants, $65.2 \%(\mathrm{n}=118)$ lived in the city center, $20.4 \%(\mathrm{n}=37)$ lived in the district, and the remaining $14.4 \%(\mathrm{n}=$
26) lived in the village. It was found out that most of the participants graduated from high school, worked full-time, and had health insurance (Table 1).

Smokers constituted $33.9 \%(\mathrm{n}=61)$ of the participants. Of the participants, $31.8 \%$ (n $=57$ ) had at least one chronic disease and were using medication to treat their chronic disease. The individuals, who reported to have previously experienced any disease related to the prostate gland, constituted $16 \%(\mathrm{n}=29)$ of the cases (Table 2). Of the participants, $88.4 \%(\mathrm{n}=$ 
159) had no prostate cancer history in their background and family history. The prevalence of any disease related to the prostate gland $(20 \%)$ was higher in the background of patients without health insurance $(p=0.0001)$. The rate of having a history of any prostate gland related disease other than prostate cancer $(3.5 \%)$ was found to be lower in individuals living in the village $(\mathrm{p}=0.04)$.

The mean score obtained from the " PCaS Test" was $3.8 \pm 2.6$. Of the participants, 92.3\% were knowledgeable at a low level and $7.7 \%$ were knowledgeable at a moderate level. It was found out that the residents of the district had relatively more knowledge scores on prostate cancer screenings $(\mathrm{p}=0.003)$. The scores received from the " $\mathrm{PCaS}$ Test" by individuals with a positive family history were higher $(p=0.002)$.

Three-quarters of men over the age of 40 had never been screened for prostate cancer before. The rate of participation in the screening programs of individuals who received a low score from the screening test was lower $(p<0.001)$. Individuals, who most frequently participated in the digital rectal examination, were found to be district residents $(\mathrm{p}=0.002)$. A family history of prostate cancer was increasing participation in both the digital rectal examination and PSA measurement $(p<0.05)$. A significant relationship was found between the habits of having the PSA measurement made in the blood for prostate cancer screening and the education level $(\mathrm{p}=0.001)$. While the habit of having PSA measurements made was the lowest in secondary school graduates $(7.4 \%)$, it was observed that the habit increased as the education level increased.

Of the participants, $16 \%(n=29)$ thought that they had enough knowledge about prostate cancer. The presence of a prostate cancer history in the family led people to express themselves as more knowledgeable $\quad(p<0.05)$. Of the individuals who thought that they were knowledgeable about prostate cancer, $35.1 \%$ acquired this knowledge from doctors, nurses or other healthcare personnel, while $21.2 \%$ stated that they acquired it from their family members and friends. The rate of individuals, who gained awareness through the internet and social media, which are very popular nowadays, was about $14.9 \%$.

Of the participants, $55.4 \%(\mathrm{n}=79)$ thought that they had enough knowledge about exercise/physical activity. When all the data were evaluated, the mean score obtained from the "E/PAALQ" was determined to be $106.3 \pm 27.2$. Most of the individuals, who stated that they did not have enough knowledge about exercise/physical activity, lived in city centers $(\mathrm{p}=0.01)$. However, the individuals who received the lowest score from the "E/PAALQ", lived in the village $(p=0.004)$. Furthermore, the average score obtained from this questionnaire by individuals with health insurance was higher $(\mathrm{p}=0.02)$.

The knowledge acquisition resources of individuals who believed that they were sufficiently knowledgeable about exercise/physical activity were in parallel with individuals who thought they had sufficient knowledge about prostate cancer. When the data were examined, the rate of individuals who indicated doctors, nurses or healthcare personnel as their source of knowledge was $28.9 \%$, and the rate of individuals acquired knowledge from their friends and family was $26.6 \%$. While the rate of individuals acquired knowledge about the subject from written or visual media was $18 \%$, the rate of individuals stating social media and the internet as the knowledge resource was $16.4 \%$. It was determined that the education level of the participants made a difference in the ways of obtaining 
knowledge $(\mathrm{p}<0.0001)$. While individuals with lower levels of education frequently regarded family/friends as the knowledge acquisition resource, individuals with especially undergraduate and higher education level frequently used written and visual communication tools.

The rate of individuals who were doing regular physical activity for 3-5 days in a week and at least for half an hour and over was $35.3 \%(n=63)$ while the rate of those who stated that they exercised at irregular intervals was $19.6 \%(\mathrm{n}=35)$. The increase in the level of education caused an increase in physical activity habits $(\mathrm{p}=$ $0.04)$.

Individuals, who had a relatively higher level of knowledge about prostate cancer screening test, had a higher level of knowledge about exercise and habit of exercising regularly $(\mathrm{p}<0.05)$, (Graph 1$)$.

Of the participants, 38.1\% $(\mathrm{n}=69)$ answered the question "Does regular exercise prevent cancer development?" as "Yes", and $8.3 \%(\mathrm{n}=15)$ as "No" and $53.6 \%(\mathrm{n}=97)$ as "I do not know." When the participants were asked the question "In which types of cancer exercise can play a preventive/protective role?", the rate of individuals who thought that exercise could prevent all kinds of cancer was in the first rank with $27.1 \%$. They were followed by individuals who thought that exercise prevented lung cancer $(16.7 \%)$ and prostate cancer $(6.3 \%)$.

Graph 1. Distribution of the physical activity habit according to the prostate cancer screening test knowledge level

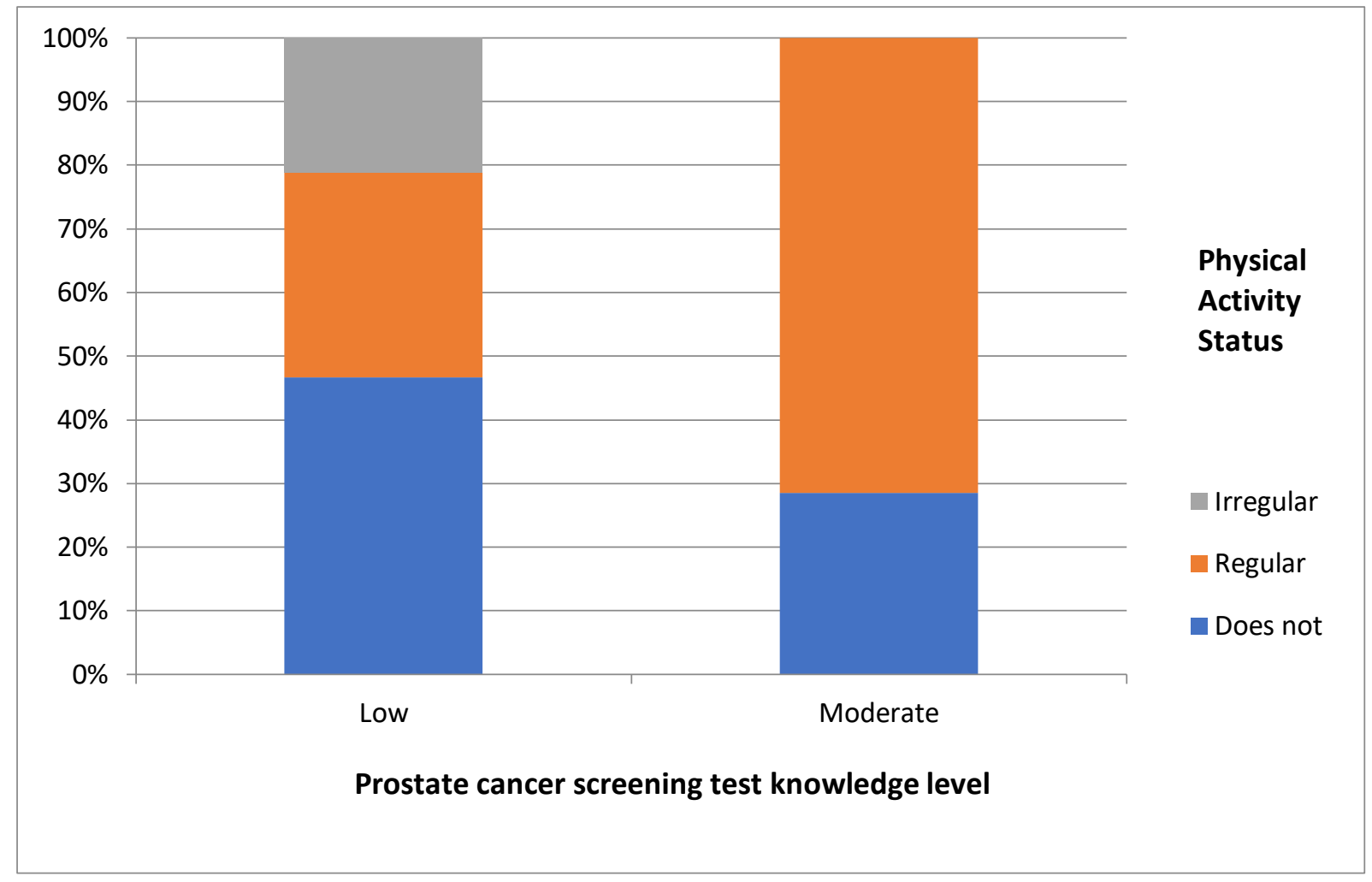




\section{Discussion}

According to the data we obtained, the society's level of knowledge about prostate cancer screening tests and participation in screening programs are low. The main factors that affect the level of knowledge and positively participation in screening programs are the positive family history and the level of education. Factors that complicate the access to healthcare providers such as the lack of health insurance and living in rural areas change the incidence of prostate gland diseases. However, the effect of these factors on the prostate cancer knowledge level and on the participation in screening programs is not significant. Individuals with a higher level of knowledge about the screening test and with a higher level of education were determined to have higher exercise awareness levels and habits. This can be considered as an indicator of increased general healthy living awareness in these people. However, it was determined that society lacks the knowledge and behavior which state that exercise can protect from cancer.

Increasing the level of knowledge about cancers having screening tests is very important in terms of public health ${ }^{19}$. Studies conducted in our country show that society does not have enough knowledge about prostate cancer screenings $^{3,24}$. In the study by Arl et al. ${ }^{3}$, the rate of individuals with low level of knowledge was $93.7 \%$ and the mean knowledge score was $4.05 \pm 2.14$. In the study by Ceyhan et al. ${ }^{24}$, the mean knowledge test score was $4.81 \pm 2.24$, and it was emphasized that the level of knowledge of the society was low. According to the data we obtained in our study, the fact that there was no one who had knowledge of prostate cancer screening at a high level in our sample group suggested that awareness should be definitely raised in the society in this regard.
In the study by Çap $1 k^{18}$, factors influencing screening test knowledge were reported to be the level of education, previous participation in the screening test, the presence of the positive family history, and the presence of health insurance. Arl1 et al. ${ }^{3}$ reported that the increase in age decreased the level of knowledge. Ceyhan et al. ${ }^{24}$ reported that the scores of individuals, who had previously received knowledge about screening tests, were higher. Mofolo ${ }^{23}$ reported that the low level of education, black race, and not knowing the language spoken in the country would be related to screening test knowledge. In our study, it was determined that this issue was related only the presence of prostate cancer history in the family $\mathrm{PCaS}$.

According to the literature, low level of knowledge about screening test is a factor reducing the participation in screening programs $^{20,24}$. The results obtained in our study were also in this direction. While individuals with low level of knowledge about screening participate less in screening programs, the rate of participation in these programs increases as the level of education increases and when the family has a history of cancer.

Zare et al. ${ }^{20}$ state that society's PCaS can be increased through Health Belief ModelBased Education programs and individuals who have more knowledge will participate in screening programs. We believe that participation in screening programs, which offer the possibility of early diagnosis, should be increased by increasing the level of knowledge about screening in our society.

Prostate cancer is a cancer type which can be diagnosed early and of which risk can be reduced when regular exercises are done and healthy living habits are applied $^{12}$. Morrison et al. $^{8}$ reported that Jamaican men had moderate levels of PCaS. However, factors such as healthy 
eating habits and regular exercise participation, which can be modified and which are protective against prostate cancer, were stated not to be implemented mostly. Unfortunately, the results we obtained in our study were more negative because, while Morrison et al. ${ }^{8}$ reported that the rate of individuals who did not exercise regularly was $35 \%$, in our study, the rate of individuals, who stated that they did exercise regularly, was determined to be $35.3 \%$.

Social media digital platforms and other means of communication are extremely popular nowadays as a source of knowledge on health-related issues ${ }^{22,} 26$. Merten et al. ${ }^{1}$ stated in the study, in which they examined the level of knowledge about the factors creating cancer risk in young men, that the increase in the level of education caused an increase in the use of the internet as a source of knowledge. In our study, it was determined that the increase in the level of education provided the acquisition of exercise knowledge from written and visual communication tools. From this point of view, we think that especially in communities which are young and have higher education level, written and visual communication tools, which include the Internet, can be benefited from in order to improve the awareness of exercise, to teach cancer screening programs and to improve public health.

When we handle healthy living habits as a whole, as in cancer screening test knowledge, an increase also in the level of knowledge about exercise and physical activity leads to the increase in physical activity habit ${ }^{25}$. The data we obtained in our study were also in this direction. It is necessary to educate all individuals in our society to develop their healthy lifestyle habits, and this knowledge should be transformed into a habit.
In the literature, it is often mentioned that exercise is protective against cancer ${ }^{27}$. However, the awareness level of this knowledge is low. For example, while students of faculties of medicine have the knowledge that physical activity is protective in chronic diseases such as coronary heart disease, hypertension, and hypercholesterolemia, they have limited knowledge about cancer ${ }^{5}$. In our study, it was determined that the knowledge about the fact that exercise could be protective against cancer was insufficient. Furthermore, it was identified that individuals, who thought that exercise was protective against cancer, could not define its relation with cancer types, such as breast, colon, etc. in which the protective effect of exercise was high ${ }^{5}$.

\section{Conclusion}

As a result, it was determined that men over the age of 40 have low-level of knowledge about prostate cancer screening tests and have moderate-level knowledge about exercise/physical activity awareness. It was identified that most of the participants did not know that exercise was protective against cancer. Therefore, in society, while increasing the knowledge of screening tests that facilitate the early diagnosis of cancer, on the other hand, the knowledge and habit level should be increased on the subject of healthy living habits such as an increase in physical activity which is preventive of cancer.

\section{Conflict of Interest}

The authors declare that they have no conflict of interest

Funding 


\section{Ethical Approval}

Ethical approval received from the Ethics Committee of Suleyman Demirel University Faculty of Medicine. (18.04.2019-2867572.050.01.04)

All participants were informed about the aims and the methods of the study and afterward they have signed the informed consent.

\section{References}

1. Merten JW, Parker A, Williams A, et al. Cancer risk factor knowledge among young adults. J Canc Educ. 2017; 32:865-70.

2. Topaktaş R, Ürkmez A, Kutluhan MA, et al. Does plasma thiol and disulphide be a new marker for prostate cancer in prostatespecific antigen level between 10 and 20 ng/ml?. Aging Male 2019; DOI: $\underline{10.1080 / 13685538.2019 .1608519}$.

3. Arli SK, Bakan AB, Yildiz M. Knowledge level about prostate cancer screenings in Turkey. Jundishapur J Chronic Dis Care. 2018;7(3):e80167.

4. Sungur M, Caliskan S. Awareness of prostate cancer diagnosis and management among Turkish males: a cross sectional study from Çorum. Aging Male 2019; DOI: 10.1080/13685538.2019.1577377

5. Amin TT, Abdelmoaty AM, Abd El Badei $\mathrm{AF}$, et al. Role of Leisure time physical activity in cancer prevention: awareness and practice among medical students at Cairo University. Asian Pac J Cancer Prev. 2017;18:135-43.

6. Hackshaw-McGeagh LE, Perry RE, Leach VA, et al. A systematic review of dietary, nutritional, and physical activity interventions for the prevention of prostate cancer progression and mortality. Cancer Causes Control. 2015;26:1521-50.

7. Bonn SE, Sjölander A, Lagerros YT, et al. Physical activity and survival among men diagnosed with prostate cancer. Cancer Epidemiol Biomarkers Prev. 2015;24:5764.

8. Morrison BF, Aiken WD, Mayhew R, et al. Prostate cancer knowledge, prevention, and screening behaviors in Jamaican men. J Canc Educ. 2017;32:352-6.

9. Owens OL, Jackson DD, Thomas TL, et al. Prostate cancer knowledge and decision making among African-American Men and women in the Southeastern United States. Int J Mens Health. 2015;14:55-70.

10. Torti DC, Matheson GO. Exercise and prostate cancer. Sports Med. 2004; 34:3639.

11. Sadeghı-Gandomanı HR, Yousefi MS, Rahımı S, et al. Incidence, risk factors, and knowledge about the prostate cancer through worldwide and Iran. WCRJ. 2017;4: e972.

12. Ballon-Landa E, Parsons JK. Nutrition, physical activity, and lifestyle factors in prostate cancer prevention. Curr Opin Urol. 2018;28:55-61.

13. Kleinman KP, McKinlay JB. Prostate cancer: how much do we know and how do we know it?. Aging Male. 2000;3:115-23.

14. Hojman P, Gehl J, Christensen JF, et al. Molecular mechanisms linking exercise to cancer prevention and treatment. Cell Metab. 2018;27:10-21.

15. Galvão DA, Taaffe DR, Spry N, et al. Enhancing active surveillance of prostate 
cancer: the potential of exercise medicine. Nat Rev Urol. 2016;13:258-65.

16. Wang Y, Jacobs EJ, Gapstur SM, et al. Recreational physical activity in relation to prostate cancer-specific mortality among men with nonmetastatic prostate cancer. Eur Urol. 2017;72:931-9.

17. Wright-St Clair VA, Malcolm W, Keogh JWL. The lived experience of physically active older prostate cancer survivors on androgen deprivation therapy. Aging Male. 2014; 17:57-62.

18. Çap 1 k C. Investigating the factors that affect the knowledge level regarding prostate cancer screenings. Turkish Journal of Urology. 2012;38:185-9.

19. Çapık C, Gözüm S. Turkısh adaptation of the knowledge about prostate cancer screening questionnaire. Turk Geriatri Derg. 2011;14:253-8.

20. Zare M, Ghodsbin F, Jahanbin I, et al. The effect of health belief model-based education on knowledge and prostate cancer screening behaviors: a randomized controlled trial. IJCBNM. 2016;4:57-68.

21. Akbarizadeh J, Gheibizadeh M, Fereidoonimoghadam M, et al. A survey of knowledge about and perceived barriers to prostate cancer screening among medical staff. Jundishapur J Chronic Dis Care. 2016;5:e31744.

22. Abdulrahman AI, Gobir AA, Abubakar AA, et al. Knowledge and practice of prostate cancer screening among men in Birnin Kudu, North-Western Nigeria. Int J Med Health Dev. 2016; 21:10-5.

23. Mofolo N, Betshu O, Kenna O, et al. Knowledge of prostate cancer among males attending a urology clinic, a South African study. Springerplus. 2015;4:67.
24. Ceyhan Ö, Göriş S, Demirtaş A, et al. Erkek hastaların prostat kanseri taramaları hakkında bilgi düzeyleri. Kırıkkale Üniversitesi Tıp Fakültesi Dergisi. 2018;20:184-91.

25. Tuncel-Dolaşır S, Tuncel F. Determining the health-exercise/physical activity levels of the Turkish university students. Celal Bayar Üniv BESBD. 2009;4:51-8.

26. $\mathrm{Xu} \mathrm{S}$, Markson $\mathrm{C}$, Costello $\mathrm{KL}$, et al. Leveraging social media to promote public health knowledge: example of cancer awareness via Twitter. JMIR Public Health Surveill. 2016;2:e17.

27. Young-McCaughan S. Potential for prostate cancer prevention through physical activity. World J Urol. 2012;30:167-79. 